\title{
Exploring Different 'Perspectives' in Secondary Geography: Professional Development Options
}

\author{
Lex Chalmers \\ Department of Geography, University of Waikato, Hamilton, New \\ Zealand
}

\section{Paul Keown}

School of Education, University of Waikato, Hamilton, New Zealand

\author{
Ashley Kent \\ Institute of Education, University of London, UK
}

Significant changes have occurred in the worlds of geography since 1973, and a substantial literature has emerged about these changes and their effects on the 'divide' between secondary and tertiarygeographers. We suggest that while the divide has not had much effect on the content taught in secondary geography in New Zealand and Britain, exposure to a range of perspectives on this content is a neglected area of professional development. Post-Fordism and deep ecology are described as perspectives that are not widely used in delivering secondary geography content. We argue firstly that effective use of different perspectives needs to be based on professional, personal and social change, and secondly that the Internet is a powerful tool in the engineering of such change.

\section{Introduction}

Teaching and learning are closely related processes; invariably we start with learning, and complement this process and skill with teaching. Teaching, as a formal activity, requires a substantial amount of learning, and reviews of geographical education internationally (Gerber \& Williams, 2000) indicate that most countries have established processes of teacher training and related research endeavours. Interestingly, the same review indicates that, in general, the research in geographical education is predominantly practice related and atheoretical (Gerber \& Williams, 2000: 212). We use British (England and Wales) and New Zealand material in our expansion of this point.

In the substantive text of this paper we first describe the paths of secondary and tertiary geography over the last two decades, arguing that the diverging paths have created tensions in both sectors. The divergence is characterised as marking a change in epoch similar to that signalling the change between interests in areal differentiation as the basis of geography and those who saw the exciting prospects of Madingley (Chorley \& Haggett, 1967). The challenges to the dominance of a scientific method implicit in Models in Geography (Chorley \& Haggett, 1967) grew with the increasing use of different, and often critical, perspectives across the social sciences. An explanation of the term (theoretical) perspectives is 
offered in the second substantive section of the paper, followed by a section describing a set of perspectives particularly relevant to geography. The links to the formal curricula (and/or syllabuses) of secondary geography are noted in the fourth section of the paper, and the final section describes ways that teachers of geography at all levels can access material relating to the selected perspectives.

\section{The Context for Concerns over the Teaching of Perspectives}

For the 50 years around the middle of the 20th Century, the links between geography and geographers in the tertiary and secondary sector were remarkably strong. Geography in Britain and elsewhere had been an indirect but important adjunct firstly to the imperial project (Walford, 2001:54) and then to an increased interest in urban and regional planning. The establishment of Chairs of Geography in university departments around the middle of the century was built on a healthy number of university entrants seeking to advance the skills and training they had acquired in the secondary system. There was also a demand for graduates in state-sponsored planning, strategic and professional fields of employment.

In the 1960s and 1970s, harmony between secondary and tertiary systems was clear. Tertiary institutions built on a substantial skills base that secondary teachers had instilled into a select range of students. University staff, in turn, contributed to resources supporting secondary teaching, most notably through the production of textbooks and as examiners at the secondary/tertiary interface. Professional and academic bodies operated through interdependent channels of communication such as the Geographical Association and Royal Geographical Society in Britain, and the New Zealand Board of Geography Teachers and the New Zealand Geographical Society.

Looking back, signals of change in this well-developed relationship were increasingly evident during the 1970s and probably reached their most intense during the 1980s. We suggest that the reflexive approaches in academic geography were not adopted across the discipline, creating some tension. Even more tension was generated by a fundamental change in the economic and social fabric of the operating environment for geographical education in Britain and New Zealand (Brown \& Smith, 2000: 256-66; Rawling, 2000). The 'sea change' in both critical awareness and 're-structuring' was particularly problematic for those emerging from geography teacher education programmes in the late 1970s. These teachers were faced with more than a decade of uncertainty about the secondary curriculum, the purpose and intent of secondary geography and the vocational options available to those who wished to study geography at advanced levels of the secondary system.

To underline our point about the sustained nature of change in the period since our chosen marker date of 1973 (Harvey's Social Justice and the City and the economic bite of the 'oil crisis'), Table 1 catalogues some of the changes that affected geography in the exemplar cases of New Zealand (NZ) and Britain (UK) and during the 20-year era of transition. The table draws on the comprehensive chronologies provided by Butterworth and Butterworth (1998).

We suggest that while policy changes are sharp, changes in the classroom are more gradual. As Rawling (2000: 212-15) indicates, disciplinary change is 
Table 1 Post-1973 influences that affected change in the teaching of geography in New Zealand and Britain

\begin{tabular}{|c|c|}
\hline 1975 (NZ) & Establishment of the National Curriculum Committee for Geography \\
\hline $1976(\mathrm{UK})$ & $\begin{array}{l}\text { Callaghan's Ruskin College speech foretells change in secondary } \\
\text { education }\end{array}$ \\
\hline 1976 (UK) & Geography 16-19 Project gives impetus to curriculum development \\
\hline 1977 (UK) & $\begin{array}{l}\text { Green paper: Education in Schools. Management options for } \\
\text { consultation }\end{array}$ \\
\hline 1984 (NZ) & $\begin{array}{l}\text { Ross Committee to review curricula, assessment and qualifications for } \\
\text { years 11-13 }\end{array}$ \\
\hline 1986 (UK) & $\begin{array}{l}\text { Creation of the Research Assessment framework to determine tertiary } \\
\text { research funding }\end{array}$ \\
\hline 1988 (UK) & $\begin{array}{l}\text { Education Reform Act defines five themes in the market phase of } \\
\text { education reform (Bell, 1999: 208-10) }\end{array}$ \\
\hline 1988 (NZ) & $\begin{array}{l}\text { Tomorrow's Schools: The Reform of Education Administration in New } \\
\text { Zealand (Picot Report) }\end{array}$ \\
\hline 1989 (NZ) & $\begin{array}{l}\text { Publication of Learning for Life: Education and Training Beyond the Age of } \\
15 \text { (Hawke Report) }\end{array}$ \\
\hline 1989 (NZ) & $\begin{array}{l}\text { Education Act abolishes Department of Education and establishes } \\
\text { multiple agencies }\end{array}$ \\
\hline 1990 (NZ) & National education Qualifications Authority (NZQA) established \\
\hline 1992 (UK) & $\begin{array}{l}\text { White Paper: Choice and Diversity market engineering in the secondary } \\
\text { sector }\end{array}$ \\
\hline 1992 (NZ) & $\begin{array}{l}\text { Bulk funding of schools option established and Education Review } \\
\text { Office (ERO) set up }\end{array}$ \\
\hline $1992(\mathrm{UK})$ & $\begin{array}{l}\text { Office for Standards in Education (OfSTED) established: } \\
\text { accountability and quality control }\end{array}$ \\
\hline 1993 (NZ) & $\begin{array}{l}\text { Publication of the New Zealand Curriculum Framework retains } \\
\text { geography's contribution to the Science and Social Sciences curricula }\end{array}$ \\
\hline
\end{tabular}

seldom driven by events in one sector alone. In a narrow sense we discerned growing dissatisfaction with the uncritical nature of geography in the late 1960s. The behavioural revolution may have provided a challenge to hegemonic (social) science, but the Vietnam War, Kent State, Paris 1968, Germaine Greer and Sergeant Pepper are icons of social change that were beyond the capacity of mainstream geography to interpret at the time. Social Justice and the City (Harvey, 1973) is useful because it was in the voice of an architect of positivist geography (Harvey, 1969), it provided a critique of the dominant theoretical perspective and it addressed social issues of significance. The essays in Billinge et al. (1984) provide wider reflections on this transitional era.

In the broader sense, beyond the immediate influence of geographers, the global economic climate was greatly affected by the 1973 oil crisis that marked the end of a long international grow th cycle within the Keynesian welfare framework (the end of the fourth Kondratiev cycle). The state, as a key investor in 
education, introduced dramatic restructuring across the economy with the now well-known forms of Reaganomics, Thatcherism and (in New Zealand) Rogernomics (Johnston et al., 2000:547,793). The most dramatic effects in education included diminished investment in resource production, centralising of policy control with devolution of implementation responsibilities, tightened accountability requirements and quality assurance programmes, reduced funding for tertiary students, and competitiveness in state funding for research. We argue that 1973 marks the start of this process, and as schools and universities confronted the new requirements, there was an inevitable refocusing. The role of the state in creating the divide in geography is widely recognised (as in the 1994 Commission on British Geography (COBRIG) meeting), but seldom seen as a macroeconomic outcome of a change in epoch.

In geography, the generally recognised point at which the separation of the interests of school and university was seen as definitive was Andrew Goudie's guest editorial in Geography (Goudie, 1993). We argue that this separation was inevitable, given 'restructuring'. Changes in classrooms were influenced by new pedagogic research, and by requirements to move secondary education away from a single academic focus towards more inclusive educational goals. Teaching this broader geography 'entitlement' requires skill and commitment, supported by good (but not atheoretical) research. We feel there are significant benefits if teachers of geography can make an awareness of critical perspectives 'seamless', with tertiary awareness of secondary curricula and secondary familiarity with the range of (critical) perspectives key elements in this process.

Rawling's (1996: 3) review of the 1994 COBRIG Seminar reveals some progress. The meeting was held in a very different environment from the Madingley meeting in 1963 (Chorley \& Haggett, 1965); the patronage of academic geography was diminished and secondary geographers were keenly involved in debates about the future of the subject. Authorship of resources for teaching secondary geography have changed and the Internet has democratised access to much geographical content. State or commercially contracted providers from the schools or training institutions are probably more relevant providers of curricula and skills-based materials.

In the area of (continuing) professional development of geography teachers, we think that an undergraduate training in geography remains vital, and we note concerns about geography being taught by non-specialists in some schools. We argue that in-service training is important, and that one of the key elements of this experience is awareness of different approaches to contemporary geographical materials. This view is not uncommon, and we draw attention to the writing of Huckle (1983), Slater (1996), and Fien (1999). The importance of awareness underpins our intention to provide accessible material for teachers in an environment that can be adapted to the needs of the individual learner.

\section{Significant Dimensions of Geographical Perspectives in Teaching and Learning}

We argue that there are benefits in being aware how knowledge about the world is organised and understood from different points of view. In geography, at the broadest level, we are interested in objects, processes and relationships as 
they relate to places and to spaces. We can see that there are different ways of looking, thinking and writing about these things. The way we organise our understanding of things affects what we can know of the geography of these things. The framework we use to organise our thinking is often called our 'perspective', sometimes (more usefully) our 'theoretical perspective'.

Part of the problem with the simple definition of the term perspective is that the word is used in a number of ways and in different contexts. When we use the term perspective in this text, we refer to theoretical perspectives or ways of looking at the world that have been adopted by a significant number of commentators. For example, the perspective promoted by Karl Marx (1818-1883) was that institutions, events and nature of places could best be understood using the process of class analysis within a perspective called historical materialism. This foundational thinker, still the focus of debate more than 100 years after his death, contributed to the construction of the historical materialism perspective, sometimes called Marxism. If we adopt a different 'perspective', we take a different view of a situation or set of events. Our perspective can be equally valid and provide as much insight about events as our original selection.

In academic geography, the most interesting and sometimes threatening outcome of growing critical awareness (Jackson, 2000:50-51) has been the questioning of the scientific perspective that dominated secondary and tertiary geography teaching from 1960 until (perhaps) the late 1980s. 'Scientific analysis' and social 'science' was so dominant that it could be described as hegemonic (a dominance allowed by unreflective acquiescence of participants in the practice of the day). Scientific knowledge was valued, and considered to be the 'truth'. The history of science in geography is well documented (Gregory, 1978); Western scientific knowledge has been built up over centuries but acquired its 'truth status' during the period of the European 'enlightenment' when the idea of 'scientific proof' became widely accepted. The scientific perspective (that values information that has been proven by set 'scientific' procedures) has been labelled 'positivism', 'empiricism' or scientific rationalism.

Perspectives such as those described as postmodern, post-colonial and feminist offered powerful critiques of the (social) sciences in the 1970s, but they have also been criticised (see, for example, Harvey's (1990) materialist critique of perspectives that argue for the importance of individual lived experience outside the larger group). We believe positivist social science has an important role, but that teachers and researchers need to be clear about the limits of the perspective they adopt, and versatile with respect to the perspectives they are prepared to consider.

\section{Choosing Perspectives}

The fourth edition of the Dictionary of Human Geography (Johnston et al., 2000) is the most comprehensive reference supporting the exploration of contemporary perspectives in geography. The richness of the listings was, however, problematic; which perspectives should we choose to illustrate our case? Three principles influenced our selection. The first was the breadth of use of the perspective in research in geography, the second considered the potential value of the perspective in secondary geography and the third was a desire to select perspectives that 
were useful in contrasting fields of content and application. Two illustrative perspectives were chosen; the post-fordist view that informs industrial and economic geographies, and the deep ecology work that adds a philosophical perspective to the positivist base of environmental science. Graduate teaching programmes in geographical education at Waikato and the Institute of Education include several more; postmodernist perspectives are included along with Marxism, feminism, post-colonialism, postmodernism and globalisation.

\section{Post-Fordist perspectives}

'Post-Fordist' has been a term increasingly attached to analyses of industrial organisation during the last decade; a usage based on the argument that a new form of industrial organisation has been increasingly prevalent since the late 1970s. The term was first given currency in the 1980s by the journal Marxism Today and its roots in Marxist analysis are reasonably clear. Post-Fordist is now used as a generic description of the changing nature of industrial capitalism and theoretical accounts of these changes. Given the breadth of these analyses, it is clearly a broad and contested concept. In the introduction to his widely cited text, Post-Fordism: A Reader, Amin (1994: 1) describes the transition in the following terms:

... the period since the mid 1970s represents a transition from one distinct phase of capitalist development to a new phase. ... there is a sense that these are times of epoch-making transformation in the very forces which drive, stabilize and reproduce the capitalist world.

The argument is that we have been living through a period of extensive economic and social transformation. Globalisation, rapid technological change, the restructuring of economic activity in both the private and public sectors, and the reorganisation of work and labour markets are just some of the forces transforming the social, economic and institutional fabric of national economies. With the benefit of hindsight, we now recognise that from approximately the time of the 1973 'oil crisis' we have seen an unravelling of the relatively stable pattern of economic growth and sustained capital accumulation that had characterised the so-called Fordist period in North America and Europe. Fordism is attached to the time-and-motion work of Taylor and the subsequent assembly line, mass production employed by Henry Ford in the following decade.

Threats to Fordism in the late 20th century, both as a production system and as a mode of economic governance or regulation, have prompted people to ask what will replace it. Lash and Urry (1987) see a movement from 'organised' and state-regulated monopoly capitalism to a 'disorganised' form, with more competition and less regulation (these processes parallel and are associated with the cultural fragmentation of modern societies known as postmodernism). For our purposes, post-Fordism can be taken to mean the new systems of organisation behind the practice of industrial organisation.

Geographies of space and place are as much affected by these new systems of organisation as they were by the practices of the first seven decades of the 20th century. Fordism left a distinct geographical imprint on cities and regions and contributed to particular 'styles' of urban and regional planning (massive industrial complexes). The extensive economic and social restructuring that has taken place since the 1970s has produced new forms of capitalist development that, in 
turn, have profoundly reshaped the geographies of urbanisation, industrialisation, and regional development. The traditional models of industrial location and organisation are ineffective, as Jackson's (2000: 54) discussion of 'Sheffield' steel reveals. The post-Fordist landscape features systems of production characterised by flexibility both of labour and machinery, the vertical break-up of large corporations, better use of links between firms (so that subcontracting is increasingly used) and by just-in-time production (Dicken, 1998).

We suggest awareness among teachers of post-Fordism as a (materialist) perspective can enrich the teaching of many topics in geography. In terms of designing professional development programmes, we advocate working extensively with a number of perspectives to encourage flexibility in the classroom. In particular curriculum areas teachers may then select useful perspectives ahead of case studies and content.

\section{Deep ecology}

Deep ecology is a term used to describe a broadly based philosophical critique of environmental science, and it is useful in providing alternative views on environment issues. The deep ecology perspective had its roots in a growing awareness of a looming environmental crisis in the 1960s. The issues had been drawn to the attention of the English-speaking world through the enormously influential works of writers such as Aldo Leopold's (1949) A Sand County Almanac and Rachel Carson's Silent Spring (1962).

The formal definition of deep ecology is attributed to Arne Naess (1973) who pointed to the limits of environmental science and management. Naess characterised the environmental concerns of government and business in the 1960s as shallow ecology that was fundamentally technocentric. Johnston et al. (2000: 157) describe the nature of the shallow ecology practice and the alternative options in the following manner:

[Shallow ecology] sought managerial solutions to environmental problems within existing socio-political frameworks ... [it was] ... also anthropocentric - in that it both saw human values as the source of all values and saw nature and environment as but a means to human ends. Against this deep ecology is ecocentric and advocates dismantling the dominant socioeconomic systems through which humans appropriate nature.

Naess struck a chord with a wide-ranging community with interests in environmental awareness and education. His philosophical position was given a practical base and broad political justification through the derivative writing of Bill Devall and George Sessions, summarised in their definitive Ecology: Living as if Nature Mattered (Devall \& Sessions, 1985).

At the broadest level, the deep ecology perspective challenges some of the teaching approaches that have underpinned our delivery of environmental issues in geography. In scientific practice, the conventional use of the term ecology involves analyses of the inter-relationships between species and their environment. In this approach, the observer is detached from the object of study. Emphasis is on measurable data of a discrete world, collected by experts who know their measurement techniques, 'facts and figures'. In contrast, deep ecology explores the environment as part of a holistic and living earth. In this 
approach, the relationship is that of an involved participant, connected with and part of the world around him or her.

The literature on deep ecology is now substantial, and there are several well-developed critiques of the approach. We review these briefly before we return to advocate awareness of the approach as a benefit in the teaching of geography. Eco-feminists make the obvious point that it is not anthropocentrism so much as androcentrism that has precipitated the environmental crisis; patriarchy is the problem. Broader is the critique of the social ecologists who point out that the environmental crisis needs to be seen it its social context; they argue that it is impossible to address environmental issues independently of issues like (neo)-colonial exploitation in Africa. We acknowledge the challenges of 'green fatigue' where a continuing emphasis on environment is seen to be incommensurate with the needs of people facing unemployment and economic insecurity. The glib response that we just need to adjust the redistributive mechanisms is not appropriate, but deep ecology does provide a useful platform for addressing this question.

The debate is on-going. Our interest in professional development with geography teachers is in complementing the perspective of environmental science with an alternative way of viewing the world. We feel the benefits of understanding a substantial critique of one approach can only strengthen our teaching capacity.

\section{Learning about Perspectives: Ongoing Professional Development}

We have discussed the 'divide' that has separated tertiary and secondary geographers increasingly since 1973, and have suggested that two processes created this divide. We have argued first that the macro-transformation of the state is underrecognised in Britain and New Zealand education, and that a series of measures listed in Table 1 contributed significantly to this divide. In this section we focus more on the second driver of the 'divide', the promotion of critical perspectives in tertiary geography, and the weak mechanisms available for the transmission of these approaches to a large cohort of teachers familiar primarily with positivist approaches to geography. We argue that awareness of these perspectives is the key issue, and note the (political) challenges of moving quickly to the adoption of these techniques in the classroom; Walford's (2001: 188-95) account of Dawn Gill's efforts to address the issues of race in the geography classroom is clear testimony to these difficulties.

A criticism sometimes levelled at teachers is that they are 'conservative' and retreat too quickly to the teaching of 'safe' topics that do not challenge the dominant (scientific) orthodoxy. We accept that there are constraints on issues that may be handled in secondary classrooms, and suggest that teachers' personal politics are more inclined to left-centre than centre-right. Further, for teachers there has been uncertainty about curriculum development in New Zealand and Britain, and in an era of massive restructuring there is some security in the use of well-developed (positivistic) resources. We will work from this position towards advocacy of professional development materials and delivery systems that meet teachers' needs.

On the basis of experience with a teacher development programme in science, Bell and Gilbert (1996) found that to be effective, teacher development requires 
that individual teachers 'develop' in three distinct ways, professionally, personally and socially (PPS). With respect to teacher development, Bell and Gilbert point out that the process should involve 'not only the use of new teaching activities in the classroom, but also the development of the beliefs and conceptions underlying the actions' (Bell \& Gilbert, 1996: 15). They maintain that if any one of these dimensions is given insufficient attention, the effectiveness of the teacher development project is threatened. The following three paragraphs summarise their discussion.

In geography, professional development is often initiated in short, taught courses where new content, ideas and techniques are 'delivered', often with exemplars. Traditionally these are offered in face-to-face meetings, often with relatively small numbers of course participants. The Internet can easily deliver content, and it also provides effective bulletin boards for the distribution of materials that support teaching. For example, in New Zealand the state-sponsored site Te Kete Ipurangi (the basket of knowledge) has exemplars of the new Level I Achievement Standard activities that were used for the first time in 2002. We suggest that the clarification of core concepts and content is important in developing new knowledge and methodological frameworks, but contemporary professional development seldom focuses on exploring beliefs and concepts. In the context of this paper, we feel the personal and social dimensions of professional development become increasingly important.

The personal dimensions teacher development involve 'each individual teacher constructing, evaluating and accepting or rejecting for herself or himself the newly constructed knowledge about what it means to be a teacher' in a given field. It also involves 'managing the feelings associated with changing their activities and beliefs', particularly if the new ideas involved go 'against the grain' of current accepted knowledge (Bell \& Gilbert, 1996: 15). In the case of the critical perspectives adopted in geographical research, the questions for teachers revolve around the extent to which they personally commit to understanding (and perhaps commit to using) the different ways of constructing relevant geographies.

Bell and Gilbert describe the social dimension of teacher development as involving 'the renegotiation and reconstruction of the rules and norms of what it means to be a teacher' of a particular subject or field. They note that teachers need to be the central contributors to this and that this needs to take place not in isolation but through social interaction. Professional development courses provide some opportunities, but much of the interaction in such courses is necessarily directive. Local networking, professional association meetings and teacherdriven local interest groups have greater potential in social development. We argue that a website managing discussion forums could overcome the shortcomings of the existing, short professional development courses.

The teacher development process outlined by Bell and Gilbert requires a significant investment of time and commitment. The Internet is useful in the process where it offers the opportunity for geography teachers to work with complex material in a time and place of their choice. At the University of Waikato we have used both websites and an Internet tutorial system (ClassForum) to deliver course material. As noted above, the delivery of content is relatively straightforward on the web, but the tutorial system adds a useful form of social development with perspectives material. The teaching staff and learners have 
Table 2 Sites identified in 'perspectives' searches in professional, and social development in geography

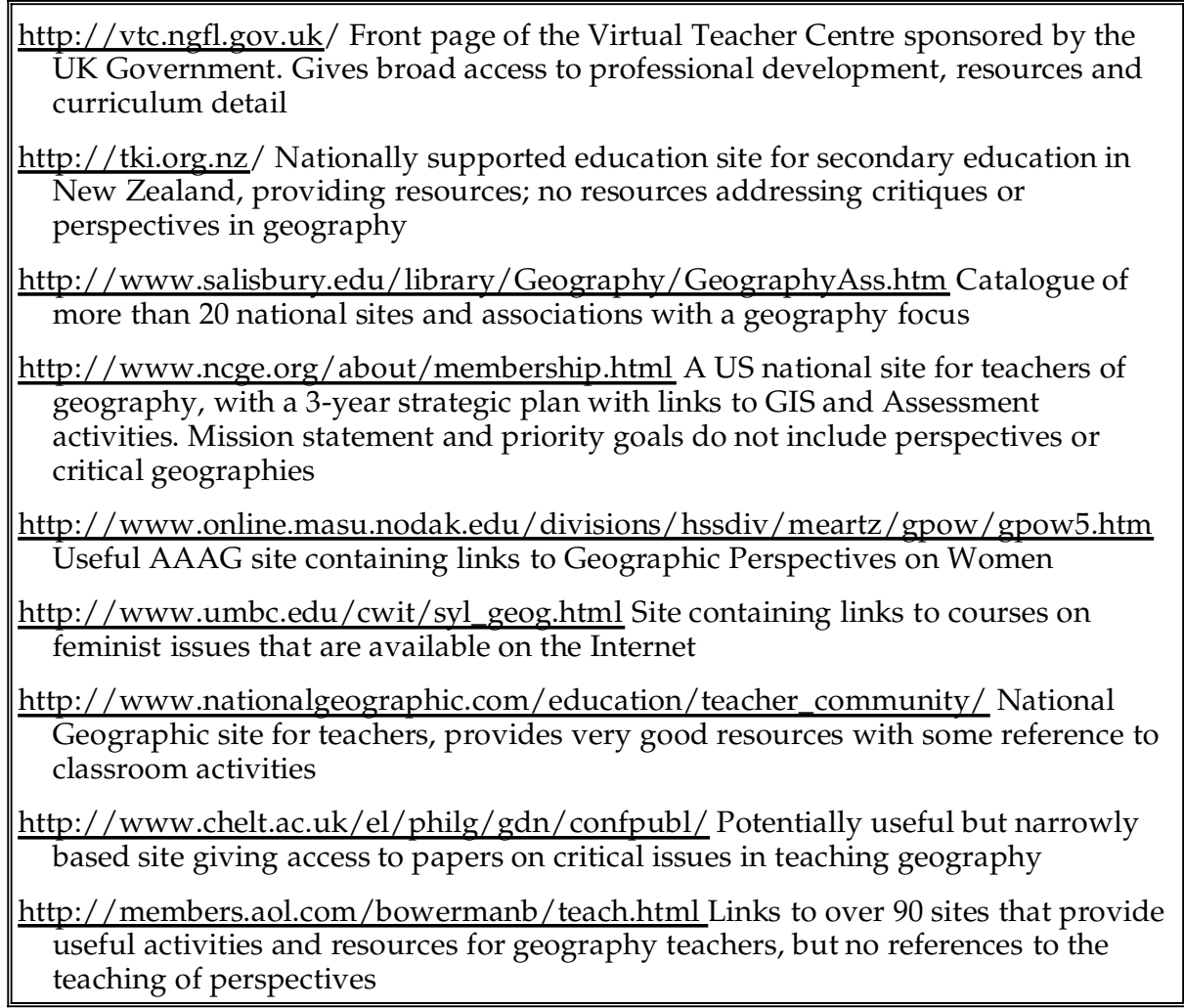

adapted readily to these systems, and we suggest that teacher development as outlined by Bell and Gilbert is well suited to e-learning technologies and could also be effective in distance learning mode.

To complete our assessment of the Internet as a professional development tool with perspectives, we carried out a series of searches. The results of the searches are consolidated in Table 2. The first Google search used 'geography teaching' and 'national'. In New Zealand, the state-sponsored Te Kete Ipurangi provides the national secondary education reference point. In Britain, the state-sponsored site is the Virtual Teacher Centre.

Given our interest in perspectives, we then looked for material related to (theoretical) perspectives in the nationally sponsored material. There were somelinks, but they were few and far between. Searching on perspectives more broadly, a third search located some excellent sites devoted to particular perspectives. For example, a Google search on 'feminist perspectives in geography' provided many site references. The critical perspectives' sites in geography were well documented, and generally related to courses offered in tertiary institutions. Our fourth search was for sites that offered material suitable for the professional development of geographers on a range of perspectives. The Google search 
terms were +course +'geographical perspectives' +critical. The sites identified were potentially useful, but almost exclusively available as advanced courses in an undergraduate degree. However, the frameworks used in these courses and the questions they addressed suggest that an increasing number of undergraduate geographers do have some (mandatory?) contact with perspectives.

In summary, we believe the Internet has already demonstrated the capacity to deliver the professional part of teacher development as outlined by Bell and Gilbert (1996). Content and exemplars of teaching units are plentiful. Material on perspectives is less evident, and tends to be found in tertiary teaching sites. Few sites promoted opportunities for the Bell and Gilbert's social development, but we believe that tutorial systems such as ClassForum have much to offer.

\section{Conclusions and Prospect}

The paper began by documenting the origins and nature of the changes that have affected secondary and tertiary geographies since the early 1970s. With reference to the increasing emphasis on critical geographies in the university system, our explanation drew on familiar content, but we see the ideology and role of the state's macro-economic strategies as more important than individual policies (such as the implementation of the RAE in Britain or the establishment of the National Curriculum framework in New Zealand). We argued that these changes have had some benefits, but that a significant cost has been the diminished contacts between geographical researchers and those teaching in the secondary sector. We suggest that, given the increased demands on teachers, in-service courses that offer classroom content, lesson plans and administrative support will continue to be in demand and well subscribed, while courses that support teacher education alone will be less popular.

In the paper we noted the increasing range of the perspectives adopted in geographical research, and we selected two examples that provide interesting and relevant ways of viewing the geographies of space and place. The post-Fordist and deep ecology perspectives are useful in two significant areas of geography, the exploration of urban-industrial complexes and in environmental issues. We suggest that the beneficiaries of increased familiarity with a range of perspectives such as these will be teachers in the first instance, but that learners in the secondary system will also benefit significantly in the long run.

The work of Bell and Gilbert provided us with three views of teacher development. We acknowledge the need to keep content current, and to update skills and administrative practice. In-service courses and the Internet support these professional development needs. We argue, however, that the personal and social aspects of teacher development are not as well supported, and these elements are vital in the adoption of perspectives such as post-Fordism and deep ecology.

The final theme in the paper was the use of the Internet in the presentation and discussion of perspectives. We anticipate that social development in learning about perspectives will be increasingly mediated through tutorial tools like ClassForum. Given the constraints of time and place that govern teachers' opportunities, we think e-learning (and distance education) can provide an effective mode of teaching and learning. Our long-term goal is to extend this project. 


\section{Correspondence}

Any correspondence should be directed to Lex Chalmers, Department of Geography, Faculty of Arts and Social Sciences, University of Waikato, Private Bag 3105, Hamilton, New Zealand (lex@waikato.ac.nz).

\section{References}

Amin, A. (ed.) (1994) Post-Fordism: A Reader. Oxford: Blackwell.

Bell, B. and Gilbert, J. (1996) Teacher Development: A Model from Science Education. London: Falmer.

Bell, L. (1999) Back to the future: The development of educational policy in England. Journal of Educational Administration 37 (3), 200-28.

Billinge, M., Gregory, D. and Martin, R. (eds) (1984) Recollections of a Revolution. London: MacMillan.

Brown, S. and Smith, M. (2000) The secondary/tertiary interface. In A. Kent (ed.) Reflective Practice in Geography Teaching. London: Paul Chapman.

Butterworth, G. and Butterworth, S. (1998) Reforming Education: The New Zealand Experience 1984-1996. Palmerston North: Dunmore Press.

Carson, R. (1962) Silent Spring. Boston: Houghton Mifflin.

Chorley, R. and Haggett, P. (eds) (1965) Frontiers in Geographical Teaching: The Madingley Lectures for 1963. London: Methuen.

Chorley, R. and Haggett, P. (eds) (1967) Models in Geography. London: Methuen.

Devall, W. and Sessions, G. (1985) Deep Ecology: Living as if Nature Mattered. Salt Lake City: Peregrine Smith.

Dicken, P. (1998) Global Shift (3rd edn). New York: Guilford.

Fien, J. (1999) Towards a map of commitment: A socially critical approach to geographic education. International Research in Geographical and Environmental Education 8 (2), 140-58.

Gerber, R. and Williams, M. (2000) Overview and international perspectives. In A. Kent (ed.) Reflective Practice in Geography Teaching (pp. 209-18). London: Paul Chapman.

Goudie, A. (1993) Guest editorial: Schools and universities - the great divide. Geography 78 (4), 338-9.

Gregory, D. (1978) Ideology, Science and Human Geography. London: Hutchinson.

Harvey, D. (1969) Explanation in Geography. London: Edward Arnold.

Harvey, D. (1973) Social Justice and the City. London: Edward Arnold.

Harvey, D. (1990) Between space and time: Reflections on the geographical imagination. Annals of the Association of American Geographers 80, 418-34.

Huckle, J. (ed.) (1983) Geographical Education: Reflection and Action. Oxford: Oxford University Press.

Jackson, P. (2000) New Directions in Human Geography. In A. Kent (ed.) Reflective Practice in Geography Teaching. London: Paul Chapman.

Johnston, R., Gregory, D. and Smith, D. (eds) (2000) Dictionary of Human Geography (4th edn). Oxford: Blackwell.

Lash, S. and Urry, J. (1987) The End of Organised Capitalism. Cambridge: Polity.

Leopold, A. (1949) A Sand County Almanac. Oxford: Oxford University Press.

Naess, A. (1973) The shallow and the deep, long-range ecology movement: A summary. Inquiry 16, 95-100.

Rawling, E. (2000) Ideology, politics and curriculum change: Reflections on school geography 2000. Geography 85 (3), 212-15.

Rawling, E. and Daugherty, R. (eds) (1996) Geography into the 21st Century. Chichester: John Wiley.

Slater, F. (1996) Values: Towards mapping their location in a geography education. In A. Kent, D. Lambert, M. Naish and F. Slater Geography in Education: Viewpoints on Teaching and Learning. Cambridge: Cambridge University Press.

Walford, R. (2001) Geography in British Schools 1850-2000. London: Woburn Press. 